\title{
Peningkatan Pengetahuan Orang Tua Siswa, Guru dan Siswa SD Tunas Harapan Islam Medan tentang Pencegahan Pandemi Covid-19
}

\author{
Nevi Yanti, Fitri Yunita Batubara, Essie Octiara, dan Darmayanti Siregar \\ Fakultas Kedokteran Gigi, Universitas Sumatera Utara, Jl Alumni No.2, Medan. 20155. Indonesia \\ E-mail: nevi.yanti@usu.ac.id
}

Keywords: counseling, Covid19, knowledge, prevention

Kata Kunci:

Covid-19, penyuluhan, pengetahuan, pencegahan

\begin{abstract}
The new corona virus epidemic (Covid-19) was declared a global pandemic on March 11, 2020 by the World Health Organization (WHO). The Covid-19 mortality rate in Indonesia of $8.9 \%$ is the highest number in Southeast Asia. Knowledge of the prevention of the Covid-19 pandemic is very important to prevent the transmission of Covid-19. The purpose of this study was to determine the level of knowledge of parents, teachers, and students of Taman Harapan Islam Medan Elementary School about the prevention of the Covid-19 pandemic. This study used a pretest questionnaire for initial data collection, then counseling was carried out on the prevention of Covid-19 and for the final data collection, a post test questionnaire was used. The results of the Mann Whitney test showed that there were differences in the level of knowledge of parents and children about Covid-19 before and after counseling ( $P$ value 0.022) and there were differences in the level of knowledge of parents and children about Covid-19 after counseling ( $P$ value 0.002). So it can be concluded that there was an influence on the level of knowledge of parents and children about the spread of Covid-19 infection. Education about preventing the spread of Covid-19 to parents of students, teachers and students of the Taman Harapan Islam Medan Elementary School can provide an understanding of the importance of preventing the spread of Covid-19 and can be passed on to their families and the surrounding environment.
\end{abstract}

\section{ABSTRAK}

Wabah virus corona baru (Covid-19) ditetapkan sebagai pandemi global pada 11 Maret 2020 oleh World Heatlh Organization (WHO). Tingkat mortalitas Covid-19 di Indonesia sebesar 8,9\% merupakan angka tertinggi di Asia Tenggara. Pengetahuan mengenai pencegahan pandemi Covid-19 sangat penting untuk mencegah penularan Covid-19. Tujuan kegiatan ini untuk memberikan pengetahuan orang tua siswa, guru, dan siswa SD Tunas Harapan Islam Medan tentang pencegahan pandemi Covid-19. Kegiatan diawali dengan pengisian kuesioner pretest untuk pengumpulan data awal, lalu dilakukan penyuluhan mengenai pencegahan Covid-19 dan untuk pengumpulan data akhir digunakan kuesioner postest. Hasil uji Mann Whitney, menunjukkan adanya perbedaan tingkat pengetahuan orang tua dan anak mengenai Covid-19 sebelum dan sesudah dilakukan penyuluhan $(P$ value 0,022$)$ dan ada perbedaan tingkat pengetahuan orang tua dan anak mengenai Covid-19 setelah dilakukan penyuluhan ( $P$ value 0,002). Sehingga disimpulkan ada pengaruh dilakukan penyuluhan terhadap tingkat pengetahuan orang tua dan anak mengenai penyebaran infeksi Covid-19. Penyuluhan tentang pencegahan penyebaran Covid-19 pada orang tua siswa, guru dan siswa SD Tunas Harapan Islam Medan dapat memberikan pemahaman mengenai pentingnya pencegahan penyebaran Covid-19 
dan dapat diteruskan kepada keluarga serta lingkungan sekitar.

\section{PENDAHULUAN}

Coronavirus adalah virus RNA dengan ukuran partikel 120-160 nm. Virus ini utamanya menginfeksi hewan, termasuk di antaranya adalah kelelawar dan unta. Sebelum terjadinya wabah Covid-19, ada 6 jenis coronavirus yang dapat menginfeksi manusia, yaitu alphacoronavirus 229E, alphacoronavirus NL63, betacoronavirus OC43, betacoronavirus HKU1, Severe Acute Respiratory Illness Coronavirus (SARS-CoV), dan Middle East Respiratory Syndrome Coronavirus (MERS-CoV) (Zhu N et al., 2020). Coronavirus yang menjadi etiologi Covid-19 termasuk dalam genus betacoronavirus. Hasil analisis filogenetik menunjukkan bahwa virus ini masuk dalam subgenus yang sama dengan coronavirus yang menyebabkan wabah Severe Acute Respiratory Illness (SARS) pada 2002-2004 silam, yaitu Sarbecovirus (Gorbalanye $\mathrm{AE}$ et al., 2020) Atas dasar ini, International Committee on Taxonomy of Viruses mengajukan nama SARS-CoV-2.16. Pada akhir 2019, Kota Wuhan, ibu kota provinsi Hubei di China, mengalami wabah virus korona baru yang mengakibatkan lebih dari 1.800 kematian dan lebih dari 70.000 kasus infeksi yang dilaporkan dalam 50 hari pertama sejak wabah. 1 Virus baru tersebut merupakan anggota dari grup beta dari coronavirus dan dinamai Novel Coronavirus (2019-nCov). Setelah itu, Komite Internasional Taksonomi Virus (ICTV) menamai virus SARSCoV-2 pada 11 Februari 2020 dan penyakit tersebut sebagai Covid-19. (Lai C, Ko W, Tang H, 2020)

Wolrd heatlrh organization (WHO) menyatakan wabah virus corona baru (Covid-19) sebagai pandemi global pada 11 Maret 2020. Pertama kali dilaporkan di Indonesia pada tanggal 2 Maret 2020 sejumlah dua kasus. Data 19 September 2020 menunjukkan kasus yang terkonfirmasi di Indonesia berjumlah 240.687 kasus dan 9.448 kasus kematian. Tingkat mortalitas Covid-19 di Indonesia sebesar 8,9\%, angka ini merupakan yang tertinggi di Asia Tenggara.

Gejala umum Covid-19 antara lain demam, batuk kering, dan kelelahan yang dapat menyebabkan gejala serius, seperti kesulitan bernapas, nyeri dada, kesulitan berbicara, dan bergerak (WHO, 2020). SARS-CoV-2 dapat menyebar melalui penularan dari manusia ke manusia dan kontak tidak langsung dengan benda yang terkontaminasi. SARS-CoV-2 dapat ditularkan melalui tetesan cairan tubuh dari mulut atau hidung, yang dapat menyebar saat pengidap Covid-19 batuk, bersin, dan berbicara. SARS-CoV-2 tetap utuh dan menular dalam tetesan dan dapat melayang di udara hingga tiga jam (Lotfi, 2020). Selain itu, tetesan yang terkontaminasi dapat menempel pada benda-benda seperti plastik, baja tahan karat, tembaga, dan karton (Van Doralemon et al, 2020). Seseorang dapat terinfeksi jika menyentuh permukaan yang terkontaminasi benda SARS-CoV-2 kemudian melakukan kontak dengan selaput lendir seperti mata, hidung, atau mulut (WHO, 2020).

Tindakan pencegahan merupakan kunci penerapan di pelayanan kesehatan dan masyarakat. Langkah pencegahan di masyarakat adalah dengan menjaga kebersihan tangan menggunakan hand sanitizer dan mencuci tangan dengan sabun serta air mengalir, menghindari menyentuh mata, hidung dan mulut. Dan menerapkan etika batuk atau bersin dengan menutup hidung dan mulut dengan lengan atas bagian dalam. Memakai masker dan menjaga jarak (minimal 1 meter) dari orang lain. Melakukan komunikasi risiko penyakit dan pemberdayaan masyarakat untuk meningkatkan pengetahuan (Direktorat Jenderal Pencegahan dan Pengendalian, 2020). Penyakit komorbid hipertensi dan diabetes melitus, jenis kelamin laki-laki, dan perokok aktif merupakan faktor risiko dari penyakit Covid-19 (Haq N, Hassali MA, Shafie AA, Saleem F, 2020).

Survei tentang pengetahuan masyarakat terahadap Covid-19 dapat mengumpulkan informasi tentang apa yang diketahui, diyakini, dan dilakukan oleh populasi tertentu. Informasi tersebut diperlukan karena ketidakjelasan informasi dan sikap negatif masyarakat terhadap penyakit menular dapat menimbulkan distres dan kepanikan (Zhong B, Luo W, Li H, 2020). Di 
masa krisis ini, data tentang pengetahuan sangat penting untuk memahami tingkat kesadaran masyarakat tentang pengetahuan masyarakat terhadap Covid-19.

\section{METODE}

Kegiatan pengabdian pada masyarakat ini dimulai dengan menerapkan Standar Operasional Prosedur (SOP) berupa protokol Kesehatan Covid-19 diantaranya, memakai masker, mencuci tangan dan pemeriksaan suhu tubuh dengan thermogun. Kegiatan diawali dengan mengisi kuesioner pretes mengenai pencegahan infeksi virus Corona Covid-19. Kegiatan pengabdian dibuka dengan kata sambutan dari Ketua Tim Pengabdian Masyarakat, Kepala Sekolah SD Tunas Harapan Islam Medan dan dilanjutkan dengan penyuluhan kepada orang tua siswa, guru dan siswa SD Tunas Harapan Islam Medan.

Kegiatan pengabdian dilaksanakan sebagai berikut :

1. Pengabdian dilakukan oleh 4 orang dokter gigi dan 11 orang mahasiswa Fakultas Kedokteran Gigi Universitas Sumatera Utara.

2. Pengisian kuesioner pretes pencegahan infeksi virus Corona Covid-19 sebelum penyuluhan dilakukan.

3. Tim pengabdian melakukan penyuluhan mengenai pencegahan penyebaran infeksi virus Corona Covid-19 melalui media audiovisual dan memperagakan poster.

4. Sesi tanya jawab.

5. Pengisian kuesioner postes dan pengarahan kepada peserta.

6. Kegiatan untuk siswa tidak dapat dilaksanakan secara masal karena ada larangan kegiatan tatap muka di sekolah oleh Menteri Pendidikan Nasional RI. Oleh karena itu semua kegiatan diajarkan oleh guru di sekolah dan orangtua yang telah mengikuti penyuluhan.

7. Siswa diberikan kuesioner pretes mengenai pencegahan infeksi virus Corona Covid-19 sebelum penyuluhan dimulai.

8. Siswa mempraktikkan cara pencegahan penyebaran infeksi virus Corona Covid-19 secara langsung dari guru dan orangtua siswa.

9. Pengisian kuesioner postes mengenai pencegahan infeksi virus Corona Covid-19.

10. Penyebaran dan pengembalian kuesioner untuk siswa dibantu oleh guru kelas dan diserahkan kepada tim pengabdian.

\section{HASIL DAN PEMBAHASAN}

Program pengabdian kepada masyarakat oleh dosen pengabdi dilakukan di SD Tunas Harapan Islam Medan pada hari Rabu tanggal 19 Agustus 2020. Kegiatan dimulai dengan penerapan standar operasional prosedur berupa protokol kesehatan Covid-19. Kegiatan pengabdian dibuka dengan kata sambutan dari Ketua Tim Pengabdian Masyarakat, Kepala Sekolah SD Tunas Harapan Islam Medan dan dilanjutkan dengan penyuluhan kepada orang tua siswa, guru dan siswa SD Tunas Harapan Islam Medan. 

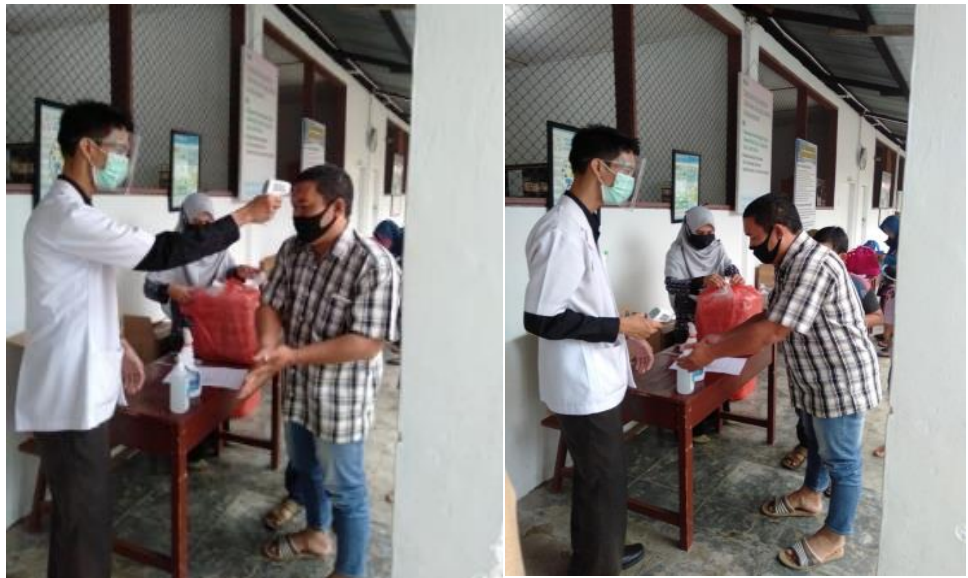

Gambar 1. Penerapan SOP Protokol Kesehatan Covid-19

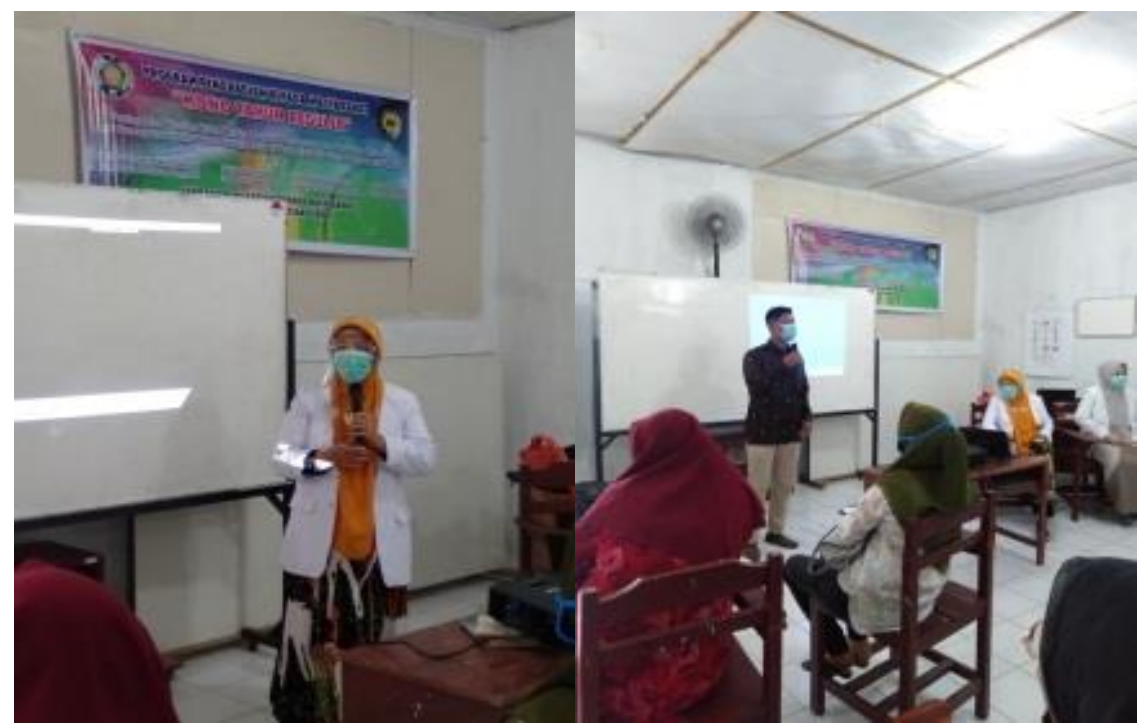

Gambar 2. Kata sambutan Ketua Tim Pengabdian USU dan Kepala Sekolah

Acara kemudian dilanjutkan dengan penyampaian materi penyuluhan mengenai pencegahan infeksi virus corona Covid-19. Penyampaian materi dilakukan dengan metode ceramah, dibantu dengan slide dan poster. Sesi selanjutnya dilakukan tanya jawab dengan pemateri dan dilanjutkan dengan pemberian kuesioner postes mengenai pencegahan infeksi virus corona Covid-19.

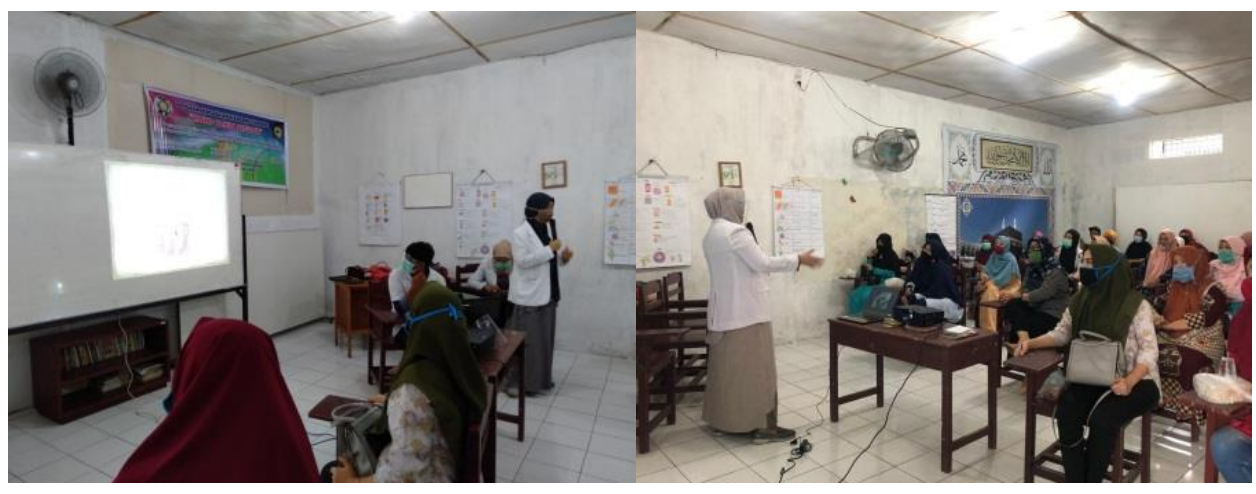

Gambar 3. Penyampaian materi pencegahan infeksi virus Covid-19 
Kegiatan untuk siswa tidak dapat dilaksanakan secara masal karena ada larangan kegiatan tatap muka di sekolah oleh Menteri Pendidikan Nasional RI. Oleh karena itu semua kegiatan diajarkan oleh guru di sekolah dan orangtua yang telah mengikuti penyuluhan. Siswa akan diberikan kuesioner pretes mengenai pencegahan infeksi virus corona COVID-19 sebelum penyuluhan dimulai. Siswa mempraktikkan cara pencegahan penyebaran infeksi virus corona COVID-19 secara langsung dari guru dan orangtua siswa. Pengisian kuesioner postes mengenai pencegahan infeksi virus corona COVID-19. Penyebaran dan pengembalian kuesioner untuk siswa dibantu oleh guru kelas dan diserahkan kepada Tim pengabdian. Sesi terakhir ditutup dengan foto bersama dengan peserta dan kepala sekolah SD Tunas Harapan Islam Medan.

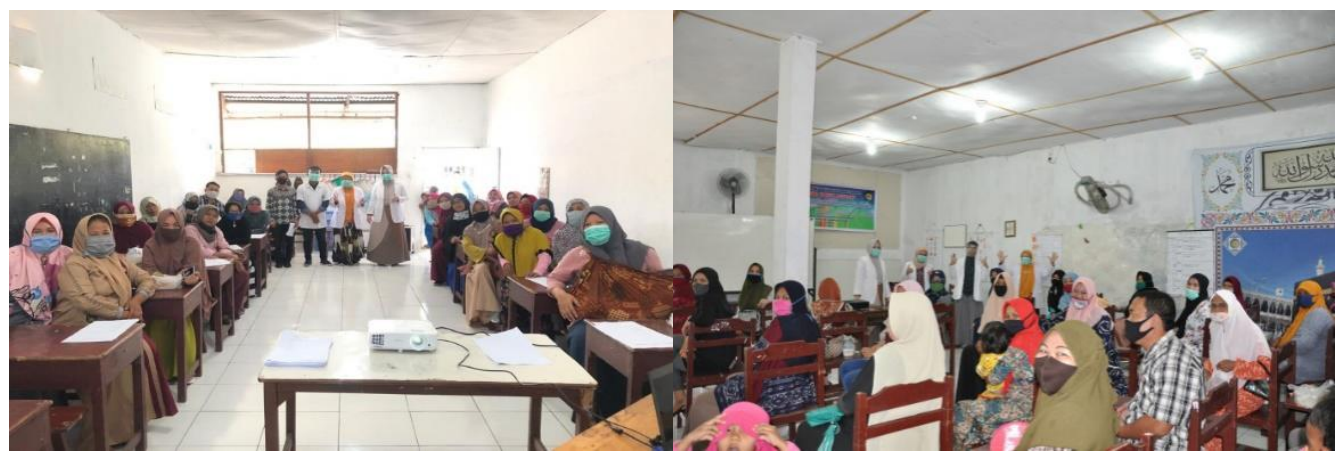

Gambar 4. Foto bersama dengan kepala sekolah serta orang tua siswa dan Guru

Hasil kuesioner pengetahuan COVID-19 pada Tabel 1 menunjukkan kategori jawaban orang tua mengenai COVID-19 ada peningkatan jumlah jawaban yang benar pada masing masing soal setelah dilakukan penyuluhan, pada kategori jawaban anak mengenai soal COVID-19 mayoritas ada peningkatan jumlah jawaban yang benar pada masing masing soal setelah dilakukan penyuluhan, namun masih terdapat beberapa soal yang tidak ada peningkatan jumlah jawaban yang benar setelah dilakukan penyuluhan.

Tabel 1. Jawaban orang tua dan anak tentang Covid-19 sebelum dan sesudah penyuluhan.

\begin{tabular}{|c|c|c|c|c|c|c|}
\hline \multirow[t]{2}{*}{ No. } & \multirow[t]{2}{*}{ Pertanyaan } & \multirow[t]{2}{*}{ Jawaban } & \multicolumn{2}{|c|}{ Jawaban Orang Tua } & \multicolumn{2}{|c|}{ Jawaban Anak } \\
\hline & & & Sebelum & Sesudah & Sebelum & Sesudah \\
\hline \multirow{6}{*}{1.} & \multirow{6}{*}{$\begin{array}{l}\text { Gejala-gejala yang sering timbul pada } \\
\text { penderita Covid 19: } \\
\text { A. Demam dan pilek } \\
\text { B. Batuk dan sesak pernafasan } \\
\text { C. Sakit tenggorokan dan lesu } \\
\text { D. Beberapa orang ada yang tidak } \\
\text { menunjukkan gejala } \\
\text { E. A, B, C dan D benar } \\
\text { Jawaban: E }\end{array}$} & A & 3 & 3 & 7 & 4 \\
\hline & & B & 7 & 2 & 30 & 11 \\
\hline & & $\mathrm{C}$ & 0 & 0 & 2 & 0 \\
\hline & & D & 0 & 0 & 3 & 0 \\
\hline & & $\mathrm{E}$ & 48 & 53 & 28 & 55 \\
\hline & & Tidak tahu & 0 & 0 & 0 & 0 \\
\hline \multirow[t]{6}{*}{2.} & \multirow{6}{*}{$\begin{array}{l}\text { Siapa saja yang dapat terkena penyakit } \\
\text { Covid-19: } \\
\text { A. Anak-anak } \\
\text { B. Orang lajut usia } \\
\text { C. Penderita kondisi medis tertentu } \\
\text { D. Semua orang } \\
\text { E. Semua orang kecuali anak-anak } \\
\text { Jawaban: D }\end{array}$} & A & 0 & 0 & 3 & 0 \\
\hline & & B & 1 & 0 & 2 & 0 \\
\hline & & $\mathrm{C}$ & 2 & 1 & 11 & 3 \\
\hline & & $\mathrm{D}$ & 53 & 57 & 46 & 38 \\
\hline & & E & 2 & 0 & 8 & 28 \\
\hline & & Tidak tahu & 0 & 0 & 0 & 0 \\
\hline \multirow{6}{*}{3.} & \multirow{6}{*}{$\begin{array}{l}\text { Apakah ada obat untuk mencegah Covid-19 } \\
\text { saat ini, agar manusia tidak sakit: } \\
\text { A. Tersedia obat antibakteri } \\
\text { B. Tersedia obat anti kuman } \\
\text { C. Tersedia obat antivirus } \\
\text { D. Tersedia vaksin virus covid } 19 \\
\text { E. Belum ada obatnya sampai saat ini } \\
\text { Jawaban: E }\end{array}$} & A & 3 & 1 & 4 & 1 \\
\hline & & B & 1 & 0 & 2 & 1 \\
\hline & & $\mathrm{C}$ & 0 & 0 & 3 & 0 \\
\hline & & $\mathrm{D}$ & 11 & 6 & 31 & 15 \\
\hline & & E & 43 & 51 & 30 & 53 \\
\hline & & Tidak tahu & 0 & 0 & 0 & 0 \\
\hline
\end{tabular}




\begin{tabular}{|c|c|c|c|c|c|c|}
\hline \multirow[t]{6}{*}{4.} & \multirow{6}{*}{$\begin{array}{l}\text { Bagaimana covid } 19 \text { dapat menular kepada } \\
\text { manusia: } \\
\text { A. Melalui hewan rumah } \\
\text { B. Melalui makanan rumah } \\
\text { C. Melalui cairan yang keluar saat penderita } \\
\text { bersin dan batuk } \\
\text { D. Melalui udara bebas } \\
\text { E. A dan B benar } \\
\text { Jawaban: C }\end{array}$} & $\mathrm{A}$ & 0 & 0 & 3 & 1 \\
\hline & & B & 0 & 1 & 1 & 1 \\
\hline & & $\mathrm{C}$ & 41 & 49 & 44 & 43 \\
\hline & & $\mathrm{D}$ & 13 & 4 & 13 & 21 \\
\hline & & $\mathrm{E}$ & 3 & 4 & 9 & 4 \\
\hline & & Tidak tahu & 1 & 0 & 0 & 0 \\
\hline \multirow{6}{*}{5.} & \multirow{6}{*}{$\begin{array}{l}\text { Bagaimana pencegahan yang dapat kita } \\
\text { lakukan agar kita tidak terpapar Covid-19: } \\
\text { A. Rajin cuci tangan dengan sabun setelah } \\
\text { berkegiatan } \\
\text { B. Menggunakan masker dan tidak } \\
\text { menyentuh mata, hidung dan mulut selama } \\
\text { berkegiatan di luar rumah } \\
\text { C. Menjaga jarak } 1-2 \text { meter dengan orang } \\
\text { lain selama berkegiatan di luar rumah } \\
\text { D. A dan B benar } \\
\text { E. A, B dan C benar } \\
\text { Jawaban: E }\end{array}$} & $\mathrm{A}$ & 3 & 4 & 14 & 4 \\
\hline & & $\mathrm{B}$ & 1 & 0 & 6 & 1 \\
\hline & & $\mathrm{C}$ & 1 & 0 & 2 & 1 \\
\hline & & $\mathrm{D}$ & 0 & 0 & 2 & 2 \\
\hline & & E & 53 & 53 & 45 & 62 \\
\hline & & Tidak tahu & 0 & 1 & 1 & 1 \\
\hline \multirow[t]{6}{*}{6.} & \multirow{6}{*}{$\begin{array}{l}\text { Berapa lama kita disarankan untuk mencuci } \\
\text { tangan untuk mencegah covid 19: } \\
\text { A. Paling sedikit 1-5 detik } \\
\text { B. Paling sedikit 5-10 detik } \\
\text { C. Paling sedikit 40-60 detik } \\
\text { D. Paling sedikit 5 menit } \\
\text { E. Paling sedikit 5-10 menit } \\
\text { Jawaban: C }\end{array}$} & A & 6 & 1 & 14 & 6 \\
\hline & & B & 33 & 9 & 20 & 8 \\
\hline & & $\mathrm{C}$ & 8 & 41 & 11 & 51 \\
\hline & & $\mathrm{D}$ & 4 & 3 & 9 & 2 \\
\hline & & $E$ & 7 & 2 & 15 & 3 \\
\hline & & Tidak tahu & 0 & 2 & 1 & 0 \\
\hline \multirow{6}{*}{7.} & \multirow{6}{*}{$\begin{array}{l}\text { Ada berapa langkah dalam mencuci tangan } \\
\text { untuk mencegah covid } 19 \text { setelah tangan } \\
\text { dibasahi oleh sabun dan air: } \\
\text { A. } 3 \text { langkah } \\
\text { B. } 4 \text { langkah } \\
\text { C. } 7 \text { langkah } \\
\text { D. } 11 \text { langkah } \\
\text { E.12 langkah } \\
\text { Jawaban: C }\end{array}$} & A & 16 & 5 & 16 & 2 \\
\hline & & B & 4 & 2 & 9 & 3 \\
\hline & & $\mathrm{C}$ & 31 & 46 & 32 & 59 \\
\hline & & D & 1 & 2 & 4 & 4 \\
\hline & & E & 5 & 1 & 9 & 2 \\
\hline & & Tidak tahu & 1 & 2 & 0 & 0 \\
\hline \multirow[t]{6}{*}{8.} & \multirow{6}{*}{$\begin{array}{l}\text { Apakah yang dimaksud dengan karantina } \\
\text { mandiri dalam pencegahan penyakit covid } \\
\text { 19: } \\
\text { A. Memisahkan orang yang sakit dengan } \\
\text { gejala COVID-19 dan mungkin menular } \\
\text { guna mencegah penularan. } \\
\text { B. Membatasi kegiatan atau memisahkan } \\
\text { orang yang tidak sakit tetapi mungkin } \\
\text { terpajan COVID -19 dengan orang lain yang } \\
\text { sehat } \\
\text { C. Menjaga jarak setidaknya } 1 \text { meter dari } \\
\text { orang lain } \\
\text { D. A dan B benar } \\
\text { E. A, B dan C benar } \\
\text { Jawaban: B }\end{array}$} & A & 14 & 9 & 21 & 12 \\
\hline & & B & 6 & 30 & 12 & 5 \\
\hline & & $\mathrm{C}$ & 0 & 1 & 9 & 2 \\
\hline & & D & 11 & 5 & 8 & 44 \\
\hline & & E & 27 & 12 & 20 & 7 \\
\hline & & Tidak tahu & 0 & 1 & 0 & 0 \\
\hline \multirow[t]{6}{*}{9.} & \multirow{6}{*}{$\begin{array}{l}\text { Apakah yang dimaksud dengan isolasi } \\
\text { mandiri dalam pencegahan penyakit covid } \\
\text { 19: } \\
\text { A.Memisahkan orang yang sakit dengan } \\
\text { gejala COVID-19 dan mungkin menular } \\
\text { guna mencegah penularan. } \\
\text { B.Membatasi kegiatan atau memisahkan } \\
\text { orang yang tidak sakit tetapi mungkin } \\
\text { terpajan COVID-19. } \\
\text { C.Menjaga jarak setidaknya } 1 \text { meter dari } \\
\text { orang lain } \\
\text { D.A dan B benar } \\
\text { E.A, B dan C benar } \\
\text { Jawaban: A }\end{array}$} & A & 15 & 35 & 19 & 9 \\
\hline & & B & 4 & 7 & 20 & 6 \\
\hline & & $\mathrm{C}$ & 1 & 2 & 7 & 2 \\
\hline & & D & 5 & 4 & 9 & 48 \\
\hline & & $\mathrm{E}$ & 32 & 9 & 16 & 5 \\
\hline & & Tidak tahu & 1 & 1 & 0 & 0 \\
\hline \multirow{5}{*}{10.} & \multirow{5}{*}{$\begin{array}{l}\text { Apakah yang dimaksud dengan social } \\
\text { distancing dalam pencegahan penyakit } \\
\text { covid } 19 \text { ? } \\
\text { A. Memisahkan orang yang sakit dengan } \\
\text { gejala COVID-19 dan mungkin menular } \\
\text { guna mencegah penularan. }\end{array}$} & $\mathrm{A}$ & 2 & 2 & 7 & 6 \\
\hline & & B & 3 & 3 & 13 & 0 \\
\hline & & $\mathrm{C}$ & 25 & 39 & 33 & 54 \\
\hline & & $\mathrm{D}$ & 1 & 1 & 6 & 4 \\
\hline & & E & 26 & 12 & 11 & 6 \\
\hline
\end{tabular}


Pada Tabel 2 menunjukkan ada peningkatan pengetahuan yang benar mengenai COVID-19 dari orang tua sebelum dan sesudah dilakukan penyuluhan, pada kategori klasifikasi jawaban anak juga mayoritas ada peningkatan pengetahuan yang benar mengenai COVID-19 dari sebelum dan sesudah dilakukan penyuluhan.

Tabel 2. Pengetahuan yang Benar Mengenai COVID-19 dari Orang Tua dan Anak Sebelum dan Sesudah Perlakuan

\begin{tabular}{|c|c|c|c|c|c|c|c|c|c|c|}
\hline \multirow{3}{*}{$\begin{array}{l}\text { No. } \\
\text { Soal }\end{array}$} & \multicolumn{4}{|c|}{ Klasifikasi Jawaban Ibu } & \multirow[t]{3}{*}{ Nilai p } & \multicolumn{4}{|c|}{ Klasifikasi Jawaban Anak } & \multirow[t]{3}{*}{ Nilai p } \\
\hline & \multicolumn{2}{|c|}{ Sebelum } & \multicolumn{2}{|c|}{ Sesudah } & & \multicolumn{2}{|c|}{ Sebelum } & \multicolumn{2}{|c|}{ Sesudah } & \\
\hline & Salah & Benar & Salah & Salah & & Salah & Benar & Salah & Benar & \\
\hline 1. & 10 & 48 & 5 & 53 & 0,125 & 43 & 27 & 15 & 55 & $<0,0001^{*}$ \\
\hline 2. & 4 & 54 & 1 & 57 & 0,375 & 23 & 47 & 29 & 41 & 0,327 \\
\hline 3. & 15 & 43 & 7 & 51 & 0,057 & 40 & 30 & 17 & 53 & $<0,0001^{*}$ \\
\hline 4. & 17 & 41 & 9 & 49 & $0,021^{*}$ & 25 & 45 & 27 & 43 & 0,832 \\
\hline 5. & 5 & 53 & 5 & 53 & 1,00 & 25 & 45 & 8 & 62 & $<0,0001^{*}$ \\
\hline 6. & 50 & 8 & 17 & 41 & $<0,0001^{*}$ & 58 & 12 & 19 & 51 & $<0,0001^{*}$ \\
\hline 7. & 27 & 31 & 12 & 46 & $0,003^{*}$ & 37 & 33 & 11 & 59 & $<0,0001^{*}$ \\
\hline 8. & 52 & 6 & 29 & 29 & $<0,0001^{*}$ & 58 & 12 & 65 & 5 & 0,092 \\
\hline 9. & 43 & 15 & 22 & 36 & $<0,0001^{*}$ & 51 & 19 & 61 & 9 & $0,021^{*}$ \\
\hline 10. & 33 & 25 & 19 & 39 & $0,001^{*}$ & 36 & 34 & 16 & 54 & $<0,0001^{*}$ \\
\hline
\end{tabular}

*Signifikan, Uji McNemar

Pada Tabel 3 berdasarkan hasil uji Wilcoxon ada perbedaan tingkat pengetahuan orang tua sebelum dan sesudah dilakukan penyuluhan $(\mathrm{p}:<0.0001)$, berarti ada pengaruh dilakukan penyuluhan terhadap tingkat pengetahuan orang tua mengenai COVID-19. Pada kategori pengetahuan anak juga terdapat perbedaan tingkat pengetahuan sebelum dan sesudah dilakukan penyuluhan ( $\mathrm{p}$ : <0.0001), berarti ada pengaruh dilakukan penyuluhan terhadap tingkat pengetahuan anak mengenai COVID-19.

Tabel 3. Tingkat Pengetahuan Orang Tua dan Anak Mengenai Covid-19 Sebelum dan Sudah Perlakuan

\begin{tabular}{lcccccc}
\hline \multirow{2}{*}{$\begin{array}{l}\text { Tingkat } \\
\text { Pengetahuan }\end{array}$} & \multicolumn{2}{c}{$\begin{array}{c}\text { Pengetahuan Orang } \\
\text { Tua }\end{array}$} & Nilai p & \multicolumn{2}{c}{ Pengetahuan Anak } & Nilai p \\
\cline { 2 - 3 } \cline { 5 - 6 } & Sebelum & Sesudah & & Sebelum & Sesudah nn & \\
\hline Baik & 7 & 36 & & 1 & 21 & \\
Sedang & 22 & 12 & $<0,0001^{*}$ & 22 & 30 & $<0,0001^{*}$ \\
Kurang & 29 & 10 & & 47 & 19 & \\
\hline
\end{tabular}

*Signifikan, Uji Wilcoxon

(Kategori Pengetahuan (Arikunto, 2006); Baik: nilai 8-10; Sedang: 6-7; Kurang: 1-5) 
Pada Tabel 4 berdasarkan hasil uji Mann Whitney ada perbedaan tingkat pengetahuan Orangtua dan Anak mengenai COVID-19 sebelum dilakukan penyuluhan ( $\mathrm{p}$ : 0.022) dan ada perbedaan tingkat pengetahuan Orangtua dan Anak mengenai COVID-19 setelah dilakukan penyuluhan ( $p$ : 0.002). Sehingga disimpulkan ada pengaruh dilakukan penyuluhan terhadap tingkat pengetahuan Orangtua dan Anak mengenai COVID-19.

Tabel 4. Perbedaan Tingkat Pengetahuan Orang Tua dan Anak Mengenai COVID-19 Sebelum dan Sudah Perlakuan

\begin{tabular}{lcccccc}
\hline \multirow{2}{*}{$\begin{array}{l}\text { Tingkat } \\
\text { Pengetahuan }\end{array}$} & \multicolumn{2}{c}{ Sebelum Perlakuan } & Nilai p & \multicolumn{2}{c}{ Setelah Perlakuan } & Nilai p \\
\cline { 2 - 3 } \cline { 5 - 6 } & $\begin{array}{c}\text { Orang } \\
\text { Tua }\end{array}$ & Anak & & $\begin{array}{c}\text { Orang } \\
\text { Tua }\end{array}$ & Anak & \\
\hline Baik & 7 & 1 & $0,022^{*}$ & 36 & 21 & $0,002^{*}$ \\
Sedang & 22 & 22 & & 12 & 30 & \\
Kurang & 29 & 47 & & 10 & 19 & \\
\hline
\end{tabular}

*Signifikan, Uji Mann Whitney

\section{KESIMPULAN}

Penyuluhan tentang pencegahan penyebaran infeksi virus corona COVID-19 pada orang tua siswa, guru dan siswa SD Tunas Harapan Islam Medan dapat memberikan pemahaman mengenai pentingnya pencegahan penyebaran virus corona COVID-19 dan dapat diteruskan kepada keluarga serta lingkungan sekitar sehingga lingkungan SD Tunas Harapan Islam Medan dapat terbebas dari penyebaran infeksi virus corona COVID-19. Hal ini dapat dibuktikan dengan penilaian pengetahuan orang tua siswa, guru dan siswa SD Tunas Harapan Islam Medan yang mengalami peningkatan dari sebelum dan setelah dilakukan penyuluhan.

\section{UCAPAN TERIMA KASIH}

Artikel ini merupakan salah satu hasil dari Program Pengabdian kepada Masyarakat yang dibiayai oleh Lembaga Pengabdian Kepada Msyarakat Universitas Sumatera Utara tahun 2020 Skema Dosen Mengabdi. Oleh karena itu, diucapkan terima kasih kepada Rektor Universitas Sumatera Utara atas dukungan dana dan fasilitas yang diberikan. Terima kasih juga kepada Mitra pada kegiatan pengabdian ini. Artikel ini merupakan salah satu hasil dari Program Pengabdian kepada Masyarakat Sumber Dana Non PNPB Universitas Sumatera Utara sesuai dengan Surat Perjanjian Penugasan Pelaksanaan Program Pengabdian kepada Masyarakat Skim Dosen Mengabdi Tahun Anggaran Nomor 297/UN5.2.3.2.1/PPM/2020.

\section{DAFTAR PUSTAKA}

Chukwumah NM, Folayan MO, Oziegbe EO, Umweni AA. 2015. Impact of Dental Caries and its Treatment on The Quality of Life of 12- to 15-year-old Adolescents in Benin, Nigeria. International Journal of Paediatric Dentistry 2015:1-11.

Direktorat Jenderal Pencegahan dan Pengendalian (P2P). Pedoman pencehagan dan pengendalian coronavirus disease (covis-19). Jakarta. Kementrian Kesehatan RI 2020. 
Fang L, Karakiulakis G, Roth M. 2020. Are Patients With Hypertension And Diabetes Mellitus At Increased Risk For COVID-19 Infection? Lancet Respir Med;20:30116-8.

Featherstone JDB. 2006. Caries Prevention and Reversal based on the Caries Balanced. Pediatric Dent J ;28(2):128.

Gorbalenya AE, Baker SC, Baric RS, de Groot RJ, Drosten C, Gulyaeva AA, et al. 2020. The species Severe acute respiratory syndrome-related coronavirus: classifying 2019-nCoV and naming it SARS-CoV-2. Nat Microbiol.

Haq N, Hassali MA, Shafie AA, Saleem F, Farooqui M, Aljadhey H. 2012. A cross sectional assessment of knowledge, attitude and practice towards Hepatitis B among healthy population of Quetta, Pakistan. BMC Public Health;12(1):1.

International Commitee on Taxonomy of Viruses. Naming the 2019 Coronavirus. Available from: https://talk.ictvonline.org. Accessed September 19, 2020

Jackson SL, Vann WF, Kotch JB, Pahel BT, Lee JY. 2011. Impact of Poor Oral health on Children's School Attendance and Performance. American J of Public Health; 10(10): 1900-1.

Karamoy Y, Tahulending A, Yuliana NM. 2014. Menilai Kualitas Hidup yang Berhubungan dengan Kesehatan Mulut Anak Berusia 12 Tahun: Validitas COHIP-SF Versi Indonesia. Cakradonya Dent J; 6(2):712.

Kemenkes RI. 2018. Laporan Nasional RISKESDAS RI. Jakarta: Kemenkes RI.

Lai -C-C, Shih T-P, Ko W-C, Tang H-J, Hsueh P-R. 2020. Severe acute respiratory syndrome coronavirus 2 (SARS-CoV-2) and coronavirus disease-2019 (COVID-19): the epidemic and the challenges. Int J Antimicrob Agents; 55(3):105924.

Lin Y, Huang L, Nie S, et al. 2011. Knowledge, attitudes and practices (KAP) related to the pandemic (H1N1) 2009 among Chinese general population: a telephone survey. BMC Infect Dish ; 11(1):128.

Lotfi M, Hamblin MR, Rezaei N. COVID-19: transmission, prevention, and potential therapeutic opportunities.2020. Clin Chim Acta.;508:254-266.

Ngantung R, Pangemanan D, Gunawan PN. 2015. Pengaruh tingkat sosial ekonomi terhadap Karies Anak di TK Hang Tuah Bitung. J eG; 3(2):542-7.

Tanzer JM. 1995. Dental Caries is a Transmissible Infectious Disease: The Keyes and Fitzgerald Revolution. J Dent Res; 74(9):1540-1.

Van Doremalen N, Bushmaker T, Morris DH, et al. 2020. Aerosol and surface stability of SARSCoV-2 as compared with SARS-CoV-1. N Engl J Med; 382(16):1564-1567.

World Health Organization Regional Office for South-East Asia 2013. Strategy for Oral Health in South-East Asia, 2013-2020. India: WHO.

World Health Organization. Q\&A on Coronaviruses (COVID-19). 2020. Available from: https://www.who.int/emergencies/diseases/novel-coronavirus-2019/question-andanswers-hub/q-a-detail/q-a-coronaviruses\#: :text=symptoms. Accessed September 19, 2020.

Yeh DY, Kuo HC, Yang YH, Ho PS. 2016. The Responsiveness of Patient's Quality of Life to Dental Caries Treatmen- A Prospective Study. PLoS ONE; 11(10): 1-12.

Yuliana.2020.Corona virus diseases (Covid 19); Sebuah tinjuan literature. Wellness and Healthy Magazine. Vol.2 No.1.,Februari 2020; 187-92.

Zhong B, Luo W, Li H, et al. 2020. Knowledge, attitudes, and practices towards COVID-19 among Chinese residents during the rapid rise period of the COVID-19 outbreak: a quick online cross-sectional survey. Int J Biol Sci ;16(10):1745-1752.

Zhu N, Zhang D, Wang W, Li X, Yang B, Song J, et al. 2020. A Novel Coronavirus from Patients with Pneumonia in China 2019. N Engl J Med;382(8):727-3. 